\title{
Mepraia spinolai in the Southeastern Pacific Ocean Coast (Chile) - First Insular Record and Feeding Pattern on the Pan de Azúcar Island
}

\author{
Hernán Sagua Franco ${ }^{+}$, Jorge Araya Rojas, Jorge González Cortes, \\ Iván Neira Cortes
}

\author{
Unidad de Parasitología, Facultad de Ciencias de la Salud, Universidad de Antofagasta, Casilla 170, \\ Antofagasta, Chile
}

In a field collection performed at Pan de Azúcar Island in Northern Chile, 95 specimens representing all instars of Mepraia spinolai were collected. The intestinal contents of 55 specimens were examined for Trypanosoma cruzi infection and were found to be negative. This is the first record of an insular habitat for M. spinolai, where the insects had fed mainly on seabirds (78\%), some on marine mammals $(5 \%)$, and some on reptiles $(7 \%)$.

Key words: Mepraia spinolai - insular habitat - blood meal - Chile

In Chile there are only two representative species of Triatominae: the domiciliary Triatoma infestans (Klug 1834) and the sylvatic Mepraia spinolai (Porter 1934) which is known only in Chile. In this country both species have been found to be naturally infected with Trypanosoma cruzi, (Miles 1976, Schenone et al.1980, Schofield et al. 1982, Apt \& Reyes 1986, Sagua 1988, Schenone \& Rojas 1989, Lent et al. 1994).

M. spinolai is the only specie of Triatominae with wing polymorphism. It is an aggressive insect which will feed on any host, even during daylight (Gajardo-Tobar 1953, Lent \& Wygodzinsky 1979, Sagua 1983, Frías et al. 1987, Canals et al. 1998). It is almost entirely sylvatic, and only occasionally reported at homes or in peridomestic habitats (Schenone et al. 1980, Schofield et al. 1982, 1998, Aguilera et al. 1986).

This study records details of fieldwork performed at Pan de Azúcar Island, located in Chilean Administrative Región III. The island is a seabirds and marine mammals national park reservation where M. spinolai was collected in all instars of its life cycle.

\footnotetext{
This work was supported from DGI-Universidad de Antofagasta, Chile.

${ }^{+}$Corresponding author. Fax: (005655) 247786. E-mail: hsagua@uantof.cl

Received 3 May 1999

Accepted 4 January 2000
}

\section{MATERIALS AND METHODS}

Pan de Azúcar island (Lat. 26' 08' S, Long. 70' $40^{\prime} \mathrm{W}$ ) is located $800 \mathrm{~m}$ from its neighboring coast. It is $182 \mathrm{~m}$ high and $5 \mathrm{~km}$ distant from the outlet stream of the same name (Pan de Azúcar), which marks the limit between the regions of Antofagasta and Atacama. In general the mainland coast of this area is stony and not very high, but is backed by a range of mountains, which can reach $595 \mathrm{~m}$ in height. The marine climate shows only slight temperature changes during the day, cloudiness that disperses at midday, high humidity, strong sunshine from the east, marine winds mainly from the west, and a saline atmosphere and soil. The Pan de Azúcar island flora and fauna are similar to those of the littoral plain of the continental area of the Atacama Desert. Cacti and bushes, marine birds, carrion birds, lizards and the marine mammals Lutra felina (sea otter) and Otaria flavescens (sea lions) are predominant on the island.

Currently this area is a natural park reservation, since Spheniscus humboldti, (Humboldt penguin) and L. felina (marine otter) have their reproductive habitats in this island.

Field and laboratory procedures - Triatomines were collected during the summer of 1995 by manual sampling, using blunt forceps. The insect presence was investigated under stones and in bird nests and involved the collection of active walking bugs. Some bugs were also captured as they approached the researchers (nymphs II and III). Bugs were maintained in flasks with corrugated filter paper as a resting site. Labelled flasks were sealed and transported to our laboratory.

In the laboratory, live and dead triatomines were counted and instars were noted. The live bugs were 
examined for anterior and posterior parasites as described by D'Alessandro (1972). Dissections were carried out in physiological saline with the intestines and genitalia being removed from the bugs (one per slide). Genitalia were preserved for histological studies. Samples of the stomach contents (promesenteron) were placed in a polystyrene microtitration plate containing drops of fresh saline in order to perform the bloodmeal analysis by double diffusion assay as described by Wisnivesky-Colli et al. (1980). Polyclonal antisera were obtained by injecting rabbits with three doses of $50 \mu \mathrm{g}$ of total proteins from marine mammal (O. flavescens), rodent (Mus musculus) and man; sea birds (including a pool of seroproteins from Larus dominicanus, L. modestus, S. humboldti and Pelecannus occidentalis), carrion birds (Cathartes aura) and reptiles (Tachymenis peruvianus).

\section{RESULTS AND DISCUSSION}

In order to characterize the M. spinolai mainland habitat in the northern Chilean coast, we carried out several field studies in wild sectors beginning in 1985. We concentrated our activities on those areas used by big herds of sea lions for reproduction and resting activities, thereby generating in their surroundings a trophic community constituted by other marine mammals, sea birds, birds of prey, and lizards. Within these same areas we have also found colonies of $M$. spinolai and ticks such as Argas neghmei.

The results of these observations have allowed us to describe this new insular habitat for $M$. spinolai on Pan de Azúcar Island. This habitat is a protected natural park reservation where $S$. humboldti (Humboldt penguin) nests during its annual migration, along with other species of sea birds such as seagulls ( $L$. dominicanus and $L$. modestus) and pelicans (P. occidentalis). Marine otters (L. felina) and sea lions (O. flavescens) are also present and it is common to observe different species of lizards that feed on the cliff's flora and marine fauna.

In our collections, we found that all stages of M. spinolai nymphs, which are normally black, used camouflage with sand grains. This camouflage obstructed our bug collection work. A similar phenomen was previously observed for Triatoma dimidiata (Zeledón et al. 1969), a vector of Chagas disease in Central America.

Table I shows the total number of bugs captured during a three day period. The prominence of young instars is notable. Mortality of young instars is probably high due to the difficulty in obtaining blood meals in this extremely isolated location. Fishermen confirmed that adults and V
TABLE I

Total Mepraia spinolai caught at Pan de Azúcar island (Chile)

\begin{tabular}{lrrrrrrr}
\hline Instars & I & II & III & IV & V & Adults & Total \\
\hline Alive & 1 & 6 & 12 & 11 & 14 & 11 & 55 \\
Dead & 4 & 4 & 10 & 9 & 5 & 8 & 40 \\
\hline Total & 5 & 10 & 22 & 20 & 19 & 19 & 95 \\
\hline
\end{tabular}

stage nymph were more commonly seen in the summer (December and January).

To our knowledge, this is the first report of a field collection of M. spinolai in an insular marine habitat. M. spinolai is unique to Chile where its geographical distribution and ecological range has been previuosly studied only in mainland populations (Schenone et al. 1980, Schofield et al. 1982, 1998, Sagua 1983).

The main sylvatic ecotopes of this species along the Pacific Ocean coast are bird nests (especially of marine birds), stony areas colonized by lizards, and locations near to the resting places of sea wolves (O. flavescens) (Lent \& Wygodzinsky 1979, Schofield et al. 1998).

Blood meal analysis was studied by double diffusion and showed that these bugs preferentially fed on sea birds $(78 \%)$, marine mammals (14\%) and lizards (7\%) (Table II). This appears to be the first record of triatomine feeding on marine mammals, however it has been previously reported that T. dimidiata and Rhodnius prolixus feed on coldblooded hosts (amphibians and reptiles) as a minor food source (5-10\%), in sylvatic areas of Central and South America (Zeledón et al. 1970, Pifano 1973). In Chile, Aguilera et al. (1986) reported bloodmeals from reptiles in six M. spinolai collected from the Chilean Administrative Region IV (Coquimbo).

\section{TABLE II}

Mepraia spinolai in Pan de Azúcar island (Chile). Blood meal analysis by double diffusion test

\begin{tabular}{lrrr}
\hline \multirow{2}{*}{ Antisera } & \multicolumn{2}{c}{ Reactive } & Non reactive \\
\cline { 2 - 3 } & No. & $\%$ & \\
\hline Otaria flavescens & 8 & 15 & 47 \\
Mus musculus & - & & 55 \\
Man (OIV-Rh+) & - & & 55 \\
Sea birds $^{a}$ & 43 & 78 & 12 \\
Cathartes aura & - & & 55 \\
Tachymenis peruvianus & 4 & 7 & 51 \\
\hline
\end{tabular}

a: pool including Larus dominicanus, L. modestus, Spheniscus humboldti and Pelecannus occidentalis. 
M. spinolai has the capacity to live in both peridomestic and sylvatic habitats but its feeding patterns and infection rates with $T$. cruzi, could vary within the different ecologic environments. In Chile two geographically separate and ecologically very different areas have been described: (a) the Pacific Ocean litoral areas of Adminstrative Regions I, II and III, where currently all M. spinolai have been collected from sylvatic environments not influenced by the human presence. These insects are always non infected by T. cruzi (Schofield et al. 1998); (b) the Intermedia and Andean areas of Administrative Regions III, IV, V and Metropolitana Region, where M. spinolai with feeding patterns including man, rodents birds, goats and reptiles have been examined. Insects that have been collected from sylvatic and domestic ecotopes showed $11.5 \%$ to $25.8 \%$ T. cruzi infection rates (Canals et al. 1998). These marked difference were observed by Barreto (1971) and Minter (1976) in domestic/peridomestic and sylvatic Panstrongylus megistus collected from very different areas of Brazil.

The finding of M. spinolai in an unusual habitat suggest that its presence in a insular sylvatic ecotope could be explained through passive transportation by marine birds or birds of prey, or perhaps by marine mammals, since these are the only fauna in the continental and insular areas.

In Chile, as in other Latin-American countries, the Pacific Ocean coast has traditionally been considered a non-active transmission area for Chagas disease. However, the existence of chagasic human infection in urban areas (González et al. 1987), along with these sylvatic $M$. spinolai foci, might open a new means for the active transmission of T. cruzi, considering that these areas are attracting ever greater numbers of tourists, sportive fishmen and scuba divers.

\section{ACKNOWLEDGMENTS}

To Dr JC Schofield for the suggestions and critical reading of the manuscript.

\section{REFERENCES}

Aguilera X, Miles MA, Apt W 1986. Triatoma spinolai in Chile: a new host for Hepatozoon triatomae. Trans R Soc Trop Med Hyg 80: 492.

Apt W, Reyes H 1986. Aspectos epidemiológicos de la enfermedad de Chagas en Chile. El territorio afectado, los vectores y la infección humana. Parasitol al Día 10: 94-101.

Barretto MP 1971. Estudos sôbre reservatórios e vectores silvestres do Trypanosoma cruzi. XLV: Inquérito preliminar sobre triatomíneos silvestres no sul do Estado do Mato Grosso, Brasil (Hemiptera, Reduviidae). Rev Brasil Biol 31: 225-233.

Canals M, Ehrenfeld M, Solis R, Cruzat L, Pinochet A,
Tapia C, Cattan P 1998. Biología comparada de Mepraia spinolai en condiciones de laboratorio y de terreno: cinco años de estudio. Parasitol al Día 22: 72-78.

D'Alessandro A 1972. New experimental vectors of Colombian Trypanosoma rangeli. J Med Entomol 9: 187-195.

Frías D, Martínez H, Wallace A 1987. Some taxonomic features of Triatoma spinolai Porter (Hemiptera: Triatominae). Acta Entomol Chil 14: 155-170.

Gajardo-Tobar R 1953. Algo más sobre Mepraia spinolai Porter (Hemiptera- Triatominae). Rev Chil Entomol 3: 117-125.

González J, Araya J, Sagua H, Cornejo J, Vargas L 1987. Infección por Trypanosoma cruzi entre habitantes de sectores no altiplánicos de la II Región, Antofagasta (1983-1985). Rev Chil Tecnol Méd 10: 503-507.

Lent H, Wygodzinsky P 1979. Revision of the Triatominae (Hemiptera:Reduviidae), and their significance as vectors of Chagas' disease. Bull American Mus Nat Hist: 163-520.

Lent H, Jurberg J, Galvão C 1994. Revalidação do Gênero Mepraia Mazza, Gajardo \& Jorg, 1940 (Hemiptera, Reduviidae, Triatominae). Rev Soc Brasil Med Trop 27 (Supl.): 163.

Miles MA 1976. Distribution and importance of Triatominae as vector of Trypanosoma cruzi. In New Approaches in American Trypanosomiasis Research, Scientific Publication No. 318, PAHO, Washington, DC, p. 48-53.

Minter DM 1976. Feeding patterns of some triatomine vectors species. In New Approaches in American Trypanosomiasis Research, Scientific Publication No. 318, PAHO, Washington, DC, p. 33-47.

Pifano CF 1973. La dinámica epidemiológica de la enfermedad de Chagas en el valle de Los Naranjos, Estado Carabobo, Venezuela. 1. Contribución al estudio de los focos naturales silvestres de Schizotrypanum cruzi Chagas, 1909. Arch Venez Med Trop Parasitol Méd 5: 3-29.

Sagua H 1983. Reduvídeos de Chile y tripanosomiasis americana: Triatoma infestans Klug,1834 y Triatoma spinolai Porter, 1934. IX Congr Latin Zool Arequipa, Peru, p. 225.

Sagua H 1988. Chagas Disease in Andean Ecosystem of Antofagasta, Chile, MSc Thesis, University of Chile, Santiago de Chile, 92 pp.

Schenone H, Rojas A 1989. Some pragmatic data and remarks related to the epidemiology of Chagas' disease. Bol Chile Parasitol 44: 66-86.

Schenone H, Villarroel F, Rojas A, Alfaro E 1980. Factores biológicos y ecológicos en la epidemiología de la enfermedad de Chagas en Chile. Bol Chile Parasitol 35: 42-54.

Schofield CJ, Apt W, Miles MA 1982. The ecology of Chagas' disease in Chile. Ecol Dis 1: 117-129.

Schofield CJ, Apt W, Sagua H, Panzera F, Dujardin JP 1998. Alary polymorphism in Triatoma spinolai and its possible relationship with demographic strategy. Med Vet Entomol 12: 30-38.

Wisnivesky-Colli C, Frey C, Solarz N 1980. Detec- 
tion of host proteins in the intestine of Triatoma infestans by agar double diffusion tests. Rev Inst Med Trop São Paulo 22: 118-123.

Zeledón R, Guardia VM, Zúñiga A, Swartzwelder JC 1970. Biology and ethology of Triatoma dimidiata (Latreille, 1811). I. Lyfe cycle, amount of blood ingested, resistance to starvation and size of adults. J Med Entomol 7: 313-319.

Zeledón R, Zúñiga A, Swartzwelder C 1969. The camouflage of Triatoma dimidiata and the epidemiology of Chagas' disease. Bol Chile Parasitol 24: 106108. 